\title{
Development and Validation of HPLC Method Using Hydrotropic Mobile Phase for the Estimation of Gatifloxacin
}

\author{
Vandana B Patel ${ }^{1 *}$, Matungi B Patel ${ }^{1}$, Dimal A Shah ${ }^{1}$ and Rajesh K Maheshwari ${ }^{2}$ \\ ${ }^{1}$ Babaria Institute of Pharmacy, Vadodara, Gujarat, India \\ ${ }^{2}$ Department of Pharmacy, Shri G S Institute of Technology and Science, Indore, India
}

\begin{abstract}
In the present work eco-friendly, precise, accurate RP-HPLC method has been developed for the determination of gatifloxacin using the concept of hydrotropy. Hydrotropy is a concept of increasing solubility of a solute in water by adding an agent termed as hydrotropes. This concept reduces the use of organic solvents for analysis of drugs which makes analysis eco friendly and less expensive. The method was developed using $3 \%$ sodium benzoate (pH 6.5) as mobile phase and Shimadzu ODS-C18 column as stationary phase. The flow rate was maintained at $1.4 \mathrm{ml} / \mathrm{min}$ and detection was performed at $293 \mathrm{~nm}$ using diode array detector. The retention time was $2.5 \mathrm{~min}$ and method was found to be linear over a concentration range of $0.5-30 \mu \mathrm{g} / \mathrm{ml}$ with correlation coefficients of 0.999 . Developed method was validated as per the ICH Q2 (R1) guidelines and applied to the estimation of gatifloxacin in eye drop formulation.
\end{abstract}

\section{Keywords}

Gatifloxacin, Hydrotropy, Sodium benzoate, RP-HPLC

\section{Introduction}

Hydrotropy is a concept of increasing solubility of a solute in water by adding an agent termed as hydrotropes. Hydrotropic solvents can be as solvent in spectrophotometry and chromatography for accurate, rapid and precise analysis. Hydrotropes are amphiphilic substances composed of hydrophilic functional group used as a media for promoting solubilization of sparingly soluble substances in aqueous solution. Hydrotropes are organic salts which present in aqueous solutions can substantially improve the solubility of hydrophobic organic substances in the aqueous phase. Commonly used hydrotropes are hydroxy benzenes, hydroxy benzoates, benzene sulfonates, sodium benzoate and sodium Citrate [1-4].

Gatifloxacin (GATI) is chemically [1-cyclopropyl-6-fluoro-1, 4-dihydrogen-8-methoxy-7-(3-methyl-1-piperazinyl)-4-oxo-3quinoline] carboxylic acid (Figure 1). The molecular formula of GATI is $\mathrm{C}_{19} \mathrm{H}_{22} \mathrm{FN}_{3} \mathrm{O}_{4}$ and a molecular weight of $375.40 \mathrm{~g} /$ mol [5]. It is antibacterial drug mainly used to treat bacterial conjunctivitis by inhibiting both bacterial DNA gyrase and topoisomerase IV [6-8]. DNA gyrase is an essential enzyme that is involved in the replication, transcription and repair of bacterial DNA.

A literature survey regarding quantitative analysis revealed that various analytical methods have been reported for the estimation of GATI. Estimation of GATI in Human Plasma and Blood has been reported using methods like RP-HPLC, UV Spectroscopy \& HPTLC from bulk and tablet dosage form
[9-38]. No liquid chromatographic method has been reported for the estimation of GATI using concept of hydrotropy. Most of the analytical methods uses organic solvents which<smiles>COc1c(N2CCNC(C)C2)c(F)cc2c(=O)c(C(=O)O)cn(C3CC3)c12</smiles>

Figure 1: Chemical structure of Gatifloxacin.

*Corresponding author: Vandana B Patel, Babaria Institute of Pharmacy, Vadodara-Mumbai National Highway 8, Varnama, Vadodara 391240, Gujarat, India, Tel: +91-9998107289

Accepted: October 22, 2020

Published online: October 24, 2020

Citation: Patel VB, Patel MB, Shah DA, et al. (2020) Development and Validation of HPLC Method Using Hydrotropic Mobile Phase for the Estimation of Gatifloxacin. Chromatogr Spectrosc Tech 3(1):28-33 
Citation: Patel VB, Patel MB, Shah DA, et al. (2020) Development and Validation of HPLC Method Using Hydrotropic Mobile Phase for the Estimation of Gatifloxacin. Chromatogr Spectrosc Tech 3(1):28-33

are toxic to the environment and increases pollution. In present study, eco-friendly, cost-effective, sensitive and accurate liquid chromatographic method has been developed for the estimation of GATI from eye drop formulation.

\section{Materials and Methods}

\section{Instrument}

HPLC instrument of Agilent 1220 Infinity make with Diode array Detector (Software: Chem Station, Open LAB Control) and stationary phase Shimadzu ODS-C18 $(250 \times 4.6 \mathrm{~mm} \times 5$ $\mu \mathrm{m}$ particle size) column was used in the study. All drugs and chemicals were weighed on digital balance (Shimadzu Ltd., Japan, Model AUX220) and $\mathrm{pH}$ was measured using digital $\mathrm{pH}$ meter (Equip tronics, India, Model EQ-610). Mobile phase and samples were sonicated using Ultrasonicator (EIE Instruments Pvt.Ltd., India).

\section{Chemicals and reagents}

Gatifloxacin was obtained as gift samples from Primal Enterprise Limited, India. Sodium benzoate (HPLC grade) and water of HPLC Grade were purchased from Merck Ltd., India. Methanol of HPLC grade was purchased from Thermo fisher scientific Pvt. Ltd., India while glacial acetic acid analytical reagent grade were purchased from S.D. Fine Chem. Ltd., India.

\section{Chromatographic conditions}

The HPLC system was equilibrated with the mobile phase $3 \%$ sodium benzoate $(\mathrm{pH} 6.5)$ before starting analysis for 30 minutes. The flow rate was maintained at $1.4 \mathrm{ml} / \mathrm{min}$ and eluent were monitored with DAD detector at $293 \mathrm{~nm}$. Total run time was kept at 5 min.

\section{Preparation of working standard solution (100 $\mu \mathrm{g} / \mathrm{ml})$}

GATI (10 mg) was accurately weighed and transferred to $10 \mathrm{ml}$ volumetric flask. Methanol was added and swirled to dissolve the drug. Volume was made up to the mark with methanol in order to prepare standard stock solution of 1000 $\mu \mathrm{g} / \mathrm{ml}$ solution. $1 \mathrm{Vml}$ of this solution was withdrawn in $10 \mathrm{ml}$ volumetric flask and volume was made to $10 \mathrm{ml}$ with methanol to get working standard solution of $100 \mu \mathrm{g} / \mathrm{ml}$.

\section{Method validation}

Validation of the developed RP-HPLC method was carried out according to International Conference on Harmonization (ICH) guidelines Q2 (R1) for specificity, sensitivity, accuracy, precision, repeatability, and robustness [39].

\section{Linearity}

Calibration curve was prepared by taking appropriate aliquot of working standard solution in different $10 \mathrm{ml}$ volumetric flask. The volume was made up to $10 \mathrm{ml}$ using mobile phase as a solvent to obtain final concentration of 0.5-30 $\mu \mathrm{g} /$ $\mathrm{ml}$. The calibration curve was plotted using mean peak area versus concentration. The regression equation was computed and correlation coefficient was determined.

\section{Accuracy}

The accuracy of the method was determined by calculating recovery of GATI by method of standard additions. Known amounts of GATI $(2.5,5,7.5 \mu \mathrm{g} / \mathrm{ml})$ standard stock solutions were taken and added to pre-quantified sample mixture. The solution was injected into HPLC system and analyzed by proposed method. The amount of GATI was estimated by measuring the areas and by fitting these values to the straight-line equations of the calibration curves.

\section{Intermediate precision}

Intraday precision was determined by analyzing sample solutions of GATI $(0.5,5$ and $30 \mu \mathrm{g} / \mathrm{ml})$ at three levels covering low, medium and high concentrations of the calibration curve three times on the same day. Interday precision was determined by analyzing sample solutions of GATI $(0.5,5$ and $30 \mu \mathrm{g} / \mathrm{ml}$ ) at three levels covering low, medium, and high concentrations over a period of 3 days. The peak areas were obtained and RSD values were determined.

\section{Repeatability}

Repeatability of sample application was assessed by analyzing GATI $(5 \mu \mathrm{g} / \mathrm{ml})$ six times and peak area was recorded. The percent relative standard deviation (\% RSD) of mean peak areas was obtained.

\section{Specificity}

Specificity is the ability to assess unequivocally the analyte in the presence of excipients, degradants, impurities which may be expected to be present. The specificity of method was ascertained by analysing GATI in presence of excipient like benzalkonium chloride (0.02\%) and interference was noted.

\section{Sensitivity}

The limit of detection (LOD) is defined as the lowest concentration of an analyte that can reliably be differentiated from background levels. The limit of quantification (LOQ) of an individual analytical procedure is the lowest amount of analyte that can be quantitatively determined with suitable precision and accuracy.

Limit of detection (LOD) and limit of quantitation (LOQ) for HPLC method were calculated by using the equation given in ICH Q2 (R1) guideline. LOD = $3.3 \times \sigma / S$, LOQ = $10 \times \sigma / S$; Where, $\sigma=$ Standard deviation of $y$ intercepts of regression line obtained from calibration cure, $S=$ Mean slope of calibration curve.

\section{Robustness}

Small deliberate changes were introduced in the chromatographic conditions to observe the effect of such changes. Flow rate and mobile phase composition were changed upto $\pm 10 \%$ and the effects on the results were examined. Robustness of the method was determined at concentration level of $5 \mu \mathrm{g} / \mathrm{ml}$ of GATI. The mean and \% RSD values of the peak areas were calculated.

\section{System suitability}

System suitability tests were carried out on freshly pre- 


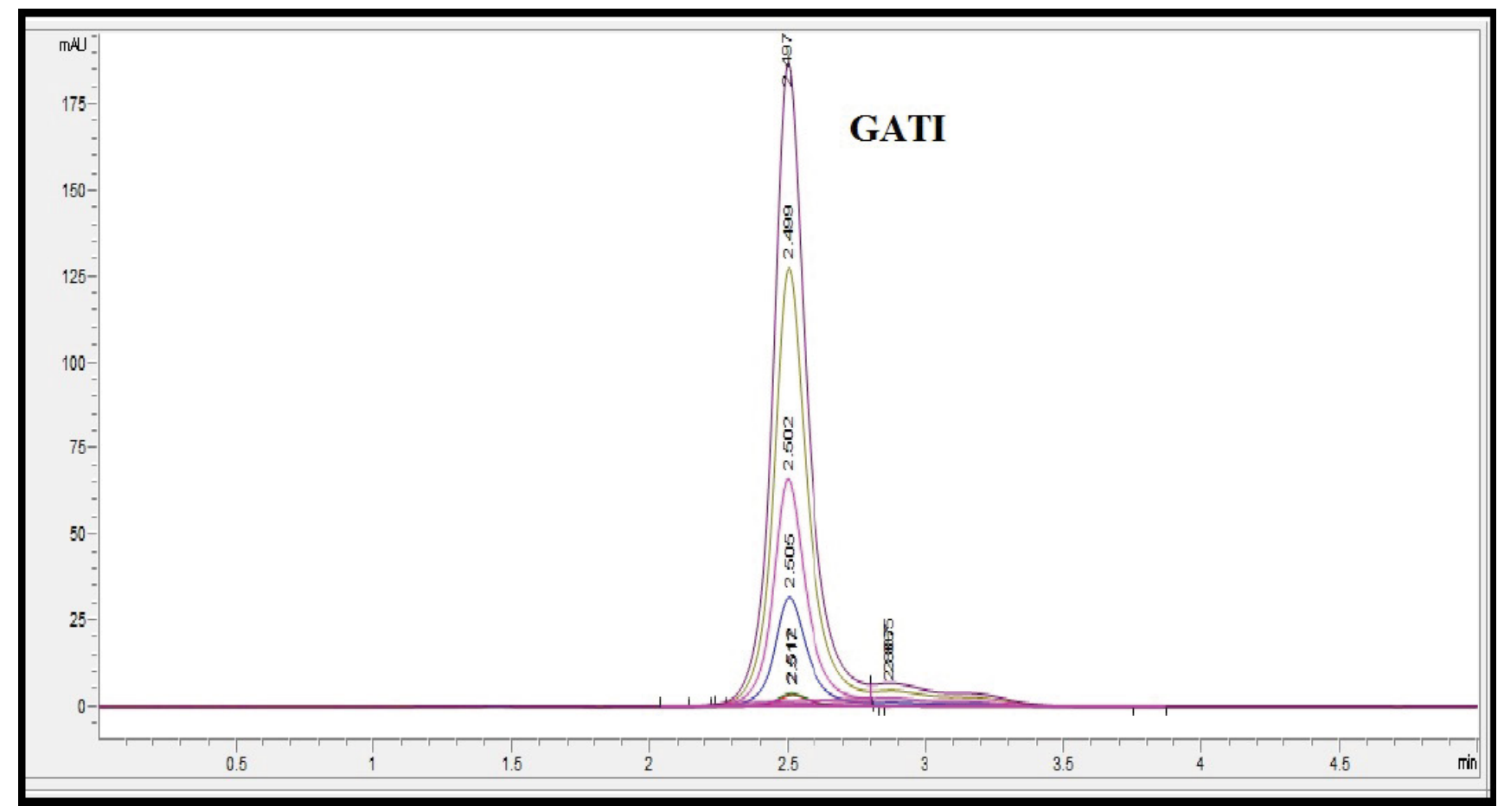

Figure 2: Overlay chromatogram of Gatifloxacin $(0.5-30 \mu \mathrm{g} / \mathrm{mL})$ in mobile phase $3 \%$ sodium benzoate $(\mathrm{pH} 6.5)$.

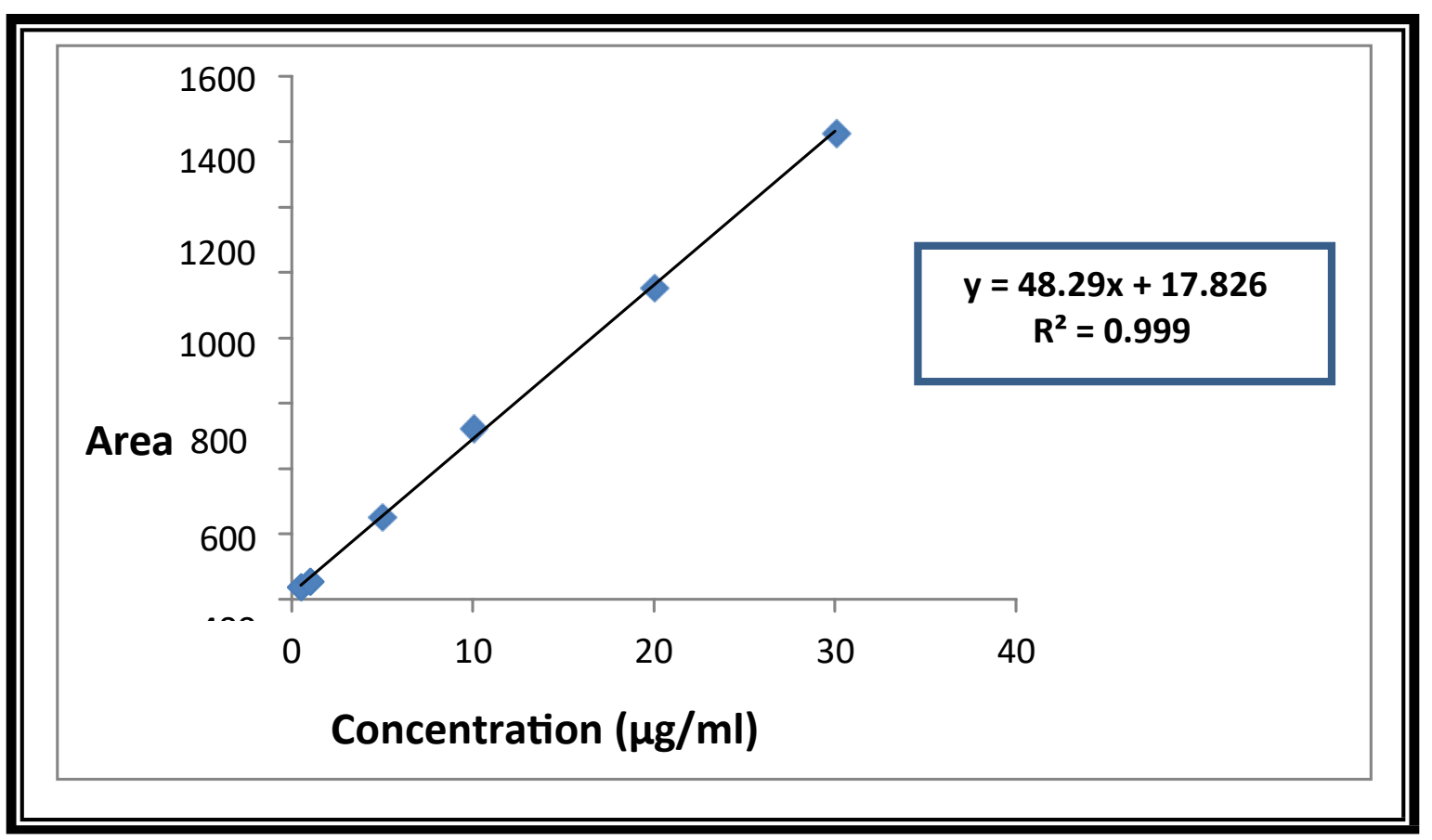

Figure 3: Calibration curve of Gatifloxacin.

pared standard stock solution of GATI. A solution of $5 \mu \mathrm{g} /$ $\mathrm{ml}$ of GATI was injected under optimized chromatographic condition and parameters such as retention time, theoretical plates, resolution etc were studied to evaluate the suitability of the system on each day.

\section{Analysis of marketed formulation}

An aliquot of eye drops equivalent to $10 \mathrm{mg}$ of GATI was transferred into a $10 \mathrm{ml}$ volumetric flask and volume was made up to $10 \mathrm{ml}$ with HPLC grade methanol to get 1000 $\mu \mathrm{g} / \mathrm{ml}$. The solution was sonicated for 5 minutes and filtered through whatman filter. Further $1 \mathrm{ml}$ aliquot from above solution was transferred in $10 \mathrm{ml}$ volumetric flask and dilution was made with methanol to get a solution of $100 \mu \mathrm{g} / \mathrm{ml}$. A $0.5 \mathrm{ml}$ sample was transferred in $10 \mathrm{ml}$ volumetric flask and diluted with mobile phase to get the concentration of $5 \mu \mathrm{g} /$ 
Citation: Patel VB, Patel MB, Shah DA, et al. (2020) Development and Validation of HPLC Method Using Hydrotropic Mobile Phase for the Estimation of Gatifloxacin. Chromatogr Spectrosc Tech 3(1):28-33

ml. Solution was injected in a system equilibrated with optimized chromatographic conditions. Peak area and retention time were obtained and quantification was carried out using regression equation.

\section{Results and Discussion}

Selection and optimization of mobile phase was performed based on ability of method to give acceptable value of theoretical plates, asymmetric factor and retention time. Different proportions of hydrotrope sodium benzoate (2-6\%) were tried with different $\mathrm{pH}$ (6-7.4) to obtain sharp peak of GATI. A mobile phase composition of $3 \%$ sodium benzoate (pH 6.5), gave sharp peak with asymmetry of 1.3 . The retention time was found to be $2.5 \mathrm{~min}$ and theroratical plates were found to be $2302 \pm 15$. Hence this mobile phase was selected as an optimized mobile phase. The overlay chromatogram of gatifloxacin has been shown in (Figure 2 and Figure 3). UV spectrum of GATI in Methanol showed absorbance maxima at $293 \mathrm{~nm}$, hence it was selected as detection wavelength.

The method was found to be linear in a concentration range of $0.5-30 \mu \mathrm{g} / \mathrm{ml}(\mathrm{n}=5)$ for GATI. The regression equation was found to be $y=48.29 \times+17.82$ with a correlation coefficient of 0.999 which indicates a good linear relationship over the concentration range studied, demonstrating the suitability of the method for analysis.

Accuracy study was performed by estimating recovery of drug. The \% recovery was found to be $98.93 \pm 0.43,99.06$ $\pm 0.15,99.44 \pm 0.54$ for $50 \%, 100 \%$ and $150 \%$ of target concentration for GATI (Table 1 and Table 2). The values near to $100 \%$ demonstrated that the method is accurate. Intra-day and Inter-day precision study was performed by taking 3 different concentrations covering entire range of the method.

Table 1: Regression analysis data.

\begin{tabular}{|l|l|}
\hline Parameters & Results \\
\hline Detection wavelength & $293 \mathrm{~nm}$ \\
\hline Linearity $(\mu \mathrm{g} / \mathrm{ml})$ & $0.5-30 \mu \mathrm{g} / \mathrm{ml}$ \\
\hline $\begin{array}{l}\text { Regression equation } \\
(\mathrm{y}=\mathrm{mx}+\mathrm{c})\end{array}$ & $\mathrm{Y}=48.29 \mathrm{x}+17.82$ \\
\hline Slop $(\mathrm{m})$ & \\
\hline Intercept $(\mathrm{c})$ & 48.29 \\
\hline Correlation coefficient $\left(\mathrm{R}^{2}\right)$ & 17.82 \\
\hline
\end{tabular}

The percentage (\%) RSD value was found to be less than $2 \%$. Repeatability study was performed by analyzing target concentration six times over a short period of time which gave $\%$ RSD value less than $1 \%$ which indicates that the method is precise.

The method was found to be specific and no interference of excipients was observed. Under the experimental conditions used, the lowest amounts of drug that could be detected (LOD) was found to be $0.1 \mu \mathrm{g} / \mathrm{ml}$ and the limit of quantification (LOQ) for GATI was found to be $0.5 \mu \mathrm{g} / \mathrm{ml}$. This indicates that the nano gram quantity of drug can be estimated accurately and precisely which indicate the sensitivity of the method. To study robustness of the method, small but deliberate changes were introduced in flow rate, $\mathrm{pH}$ and concentration of Sodium benzoate. In each study peak shape was not affected but there was variability in retention time of the GATI and the \% RSD was observed to be less than 2\% (Table 3). System suitability parameters are summarized in (Table 4).

The developed method was applied for the analysis of eye drop formulation. The \% drug content was found in the range of $99.4 \%-100.6 \%$. The analysis result of GATI eye drops complied with the specification. Hence, the developed method can be used for routine quality control test of GATI.

Table 2: Summary of validation parameter.

\begin{tabular}{|l|l|l|}
\hline Sr. no. & Parameters & Results \\
\hline $\mathbf{1}$ & Linearity and Range & \\
\hline & Range $(\mu \mathrm{g} / \mathrm{ml})$ & $0.5-30$ \\
\hline & Correlation coefficient $\left(\mathrm{R}^{2}\right)$ & 0.999 \\
\hline $\mathbf{2}$ & Precision $(\% \mathrm{RSD})$ & \\
\hline & Intra-day $(\mathrm{n}=3)$ & $0.18-1.31$ \\
\hline & Inter-day $(\mathbf{n}=\mathbf{3})$ & $0.31-1.14$ \\
\hline & Repeatability $(\mathrm{n}=6)$ & 0.853 \\
\hline $\mathbf{3}$ & LOD $(\boldsymbol{\mu g} / \mathbf{m l})$ & 0.1 \\
\hline $\mathbf{4}$ & LOQ $(\boldsymbol{\mu g} / \mathbf{m l})$ & 0.5 \\
\hline $\mathbf{5}$ & Accuracy $(\mathbf{M e a n} \pm \mathbf{S D})(\mathbf{n}=\mathbf{3})$ & \\
\hline & $\mathbf{5 0} \%$ target concentration & $98.93 \pm 0.43$ \\
\hline & $\mathbf{1 0 0} \%$ target concentration & $99.06 \pm 0.15$ \\
\hline & $\mathbf{1 5 0} \%$ target concentration & $99.44 \pm 0.54$ \\
\hline $\mathbf{6}$ & Specificity & Specific \\
\hline
\end{tabular}

Table 3: Robustness study of Gatifloxacin.

\begin{tabular}{|l|l|l|l|}
\hline Parameters & Levels & Retention time (min.) Mean \pm SD $(\mathbf{n}=\mathbf{3})$ & \% RSD \\
\hline Flow rate (ml/min.) & 1.3 & $2.533 \pm 0.031$ & 1.24 \\
\hline & 1.6 & $2.481 \pm 0.002$ & 0.10 \\
\hline \multirow{3}{*}{ pH } & 6.3 & $2.502 \pm 0.003$ & 0.14 \\
\hline Concentration & 6.7 & $2.509 \pm 0.004$ & 0.16 \\
\hline \multirow{2}{*}{ of sodium benzoate } & 2.6 & $2.530 \pm 0.003$ & 0.14 \\
\hline & 2.8 & $2.500 \pm 0.003$ & 0.12 \\
\hline
\end{tabular}


Citation: Patel VB, Patel MB, Shah DA, et al. (2020) Development and Validation of HPLC Method Using Hydrotropic Mobile Phase for the Estimation of Gatifloxacin. Chromatogr Spectrosc Tech 3(1):28-33

Table 4: System suitability parameters.

\begin{tabular}{|l|l|}
\hline Parameters & $\begin{array}{l}\text { Proposed method } \\
\text { (Mean } \pm \text { SD) }(\mathbf{n}=\mathbf{5})\end{array}$ \\
\hline Retention time (min.) & $2.5 \pm 0.12$ \\
\hline Theoretical plates (N) & $2302 \pm 15$ \\
\hline Tailing factor (T) & $1.5 \pm 0.10$ \\
\hline
\end{tabular}

\section{Conclusion}

Precise, accurate reversed phase liquid chromatographic method has been developed for the estimation of Gatifloxacin from eye drop formulation. The method utilizes an aqueous $3 \%$ solution of sodium benzoate as mobile phase which reduces the use of organic solvents. The method is less time consuming having retention time of $2.5 \mathrm{~min}$. The reported analytical methods [9-38] use organic solvents which are toxic to the environment and increases pollution. The present method is eco-friendly, cost effective, sensitive and accurate. Method was successfully used for the estimation of GATI in its formulation and it can be applied for analysis of GATI in bulk and quality control samples.

\section{Acknowledgments}

The authors are thankful to Primal Enterprise Limited, India for providing gift sample of GATI. The authors are very thankful to Principal, Babaria Institute of Pharmacy, Varnama, vadodara for providing necessary facilities to carry out research work.

\section{References}

1. Kulkrni SJ, Goswami AK (2014) Research on application of hydrotropy: A review. Int J Sci En Tech Res 3: 2617-2619.

2. Sampath KV, et al. (2014) A Rewiev on solubility enhancement using hydrotropic Phenomena. Int J Pharm 6: 1-7.

3. Maheshwari RK, Chaturvedi SC, Jian NK (2007) Novel application of hydrotropic solubilization in the analysis of some NSAIDs and their solid dosage form. Ind J Pharm Sci 69: 101-106.

4. Reddy R, Desu PK, et al. (2013) A review on hydrotropy. J Pharma Res 2: 5-6.

5. (2010) Indian pharmacopoeia, Govt. of India Ministry of health \& family welfare. The controller \& publication, Delhi 1: 157.

6. https://www.mims.com/india/drug/info/gatifloxacin

7. (2013) The Merck index, an encyclopedia of chemicals, drugs, and biological; Fifteenth Edition; Royal Society of Chemistry, 4413.

8. https://pubchem.ncbi.nlm.nih.gov/compound/Gatifloxacin

9. Petha NM, Patil JG, Chandorkar JG (2017) Development and validation of high performance liquid chromatography method for analysis of gatifloxacin \& its impurity. Pharma Tutor 5: 37-41.

10. A Caroline Grace, T Prabha, M Jagadeeswaran, et al. (2019) Stability indicating hplc method for determination of gatifloxacin in ophthalmic dosage form. Int J Pharm Sci Res 11: 1814-1820.

11. Ibrahim A Aljuffali, Mohd Abul Kalam, Yasmin Sultana, et al. (2014) Development and validation of stability-indicating high performance liquid chromatography method to analyze gatiflox- acin in bulk drug and pharmaceutical preparations. Saudi Pharm J 23: 1-10.

12. Bera AK, De AK, Pal B (2014) Simple Isocratic RP-HLC Method Development and Validation for Estimation of Gatifloxacin in Tablet Dosage Form. Int J Pharm Sci Res 5: 3741-3745.

13. Dgither SA, Alvi SN, Hammami MM (2005) Development and validation of HPLC method for the determination of gatifloxacin stability in human plasma. J Pharmaceut Biomed 251-255.

14. Borner K, Hartwing H, Lode $\mathrm{H}$ (2000) Determination of gatifloxacin in human serum and urine by HPLC. Chromatographia 52: 105-107.

15. Venugopal K, Snehalatha M, Bende G, et al. (2007) Development and validation of lon-pairing RP-hplc method for the estimation of gatifloxacin in bulk and formulation. J Chromatogr Sci 45: 220225.

16. Sirnivas N, Shankar P, Mullangi R (2008) Develoment and valodation of a HPLC method for simultaneous quantitation of gatifloxacin, sparfloxacin and moxifloxacin using levofloxacin as internal standard in human plasma: Application to a cinical pharmacokinetic study. Biomed Chromatogr 1288-1295.

17. Nirogi R, Kota S, Vennila S, et al. (2010) High performance liquid chromatographic method for the separation of Enantiomeric Gatifloxacin. J Chromatogr Sci 48: 100-103.

18. Rao AL, Kumar RBN, Sankar GG (2011) Estimation of gatifloxacin in pharmaceutical dosage forms by high performance liquid chromatography. J Pharm Pharmceu Res Health Care 3: 72-76.

19. Sivasubamanian L, Muthukumaran A (2005) RP-HPLC estimation of gatifloxacin un tablets. Indian J Pharm Sci 367-369.

20. Sanjay K Motwani, Roop K Khar, Farhan J Ahmad, et al. (2006) Stability indicating High performance thin layer chromatographic determination of Gatifloxacin as bulk drug and from polymeric nanoparticles. Anal Chim Acta 576: 253-260.

21. Sowmiya G, Gandhimathi M, TK Ravi, et al. (2007) HPTLC method for the determination of gatifloxacin in human plasma. Indian J Pharm Sci 69: 301-302.

22. Rote AR, Kumbhoje PA (2011) Development and validation of HPTLC Method for estimation of gatifloxacin and ornidazole in human plasma. J Chromat Sep Techniq 2: 1-4.

23. Sharma MC, Sharma S (2011) Development and validation of TLC densitometric method for gatifloxacin in pharmaceutical formulations. Int J Pharmtech Res 3: 1179-1185.

24. Venugopal K, Saha RN (2005) New, simple and validated UV-spectrophotometric method for the estimation of gatifloxacin in bulk and formulations. IL Farmaco 60: 906-912.

25. K Ilango, P Valentina, K S Lakshmi, et al. (2006) UV spectroscopic and colorimetric methods fpr the estimation of gatifloxacin in tablet dosage forms. Indian J Pharm Sci 68: 273-275.

26. Gandhi MB, Rao LA, Rao VJ (2015) Development and validation of spectrophotometric and stability indicating RP-HPLC method for the simultaneous estimation of gatifloxacin and flubiprofen sodium in ophthalmic dosage form. Indian J Pharm Pharmacol 2: 160-168.

27. Sireesh KR, Prakash K (2011) Simultaneous determination of gatifloxacin and dexamethasone sodium phosphate in bulk and pharmaceutical formulations by HPLC. Afr J Pharm Pharmaco 5: 1990-1995.

28. Patel P, Patel D, Desai S, Meshram D (2014) Development and 
validation of analytical methods for simultaneous estimation of Difluprednate and Gatifloxacin in ophthalmic Emulsion by UV-Visible spectroscopy. Int J Invent Pharm Sci 3: 1-10.

29. Patel AB, Shah NJ, Patel NM (2009) Development and Validation of HPLC Method for the simultaneous estimation of satranidazole and gatifloxacin in tablet dosage form. Int J Chemtech Res 1: $587-590$.

30. Sridhar S, Rayala K, Muvvala S (2015) Reverse phase high performance liquid chromatography method development and validation for the simultaneous estimation of gatifloxacin and flurbiprofen in pharmaceutical dosage form. Asian J Pharm Clin Res 8: 242-246.

31. Khan IU, Razzaq SN, Mariam I, et al. (2014) Stability indicting RP-HPLC method for simultaneous determination of gatifloxacin and flurbiprofen in binary combination. Quim. Nova 37: 349-354.

32. Raul SK, Shanmukha B, Jhansi D (2015) RP-HPLC Method development and validation for the simultaneous estimation of gatifloxacin and ambroxol $\mathrm{HCl}$ in pharmaceutical dosage form. Int J Pharm Pharm Sci 7: 121-124.

33. Premkumari KB, Murudan V, Ezhilarasan V, et al. (2016) Simultaneous estimation of loteprednol etabonate and gatifloxacin in pharmaceutical dosage form by UHPLC method. J Pharma Bio Sci 11: 82-87.
34. Razzaq SN, Mariam I, Khan Islam Ullah, et al. (2013) Development and validation of liquid chromatographic method for gatifloxacin and ketorolac tromethamine in combined dosage form. J Liq Chromatogr R T 35: 651-661.

35. Prathap B, Nagarajan G, et al. (2010) Simultaneous estimation of gatifloxacin and ambroxol $\mathrm{HCl}$ in tablet formulation by HPTLC Method. Der Pharm 2: 163-167.

36. Patel P, Patel D, Meshram D (2014) Validation of RP-HPLC Method for simultaneous determination of difluprednate and gatifloxacin in ophthalmic emulsion. Int J Adv Res 2: 484-492.

37. Prabhu SL, Thiagarajan M, et al. (2010) Simultaneous estimation of gatifloxacin and ambroxol Hydrochloride by UV-Spectrophotometry. Int J Pharm Sci Rev Res 3: 123-126.

38. Sversut RA, Alcantara IC, Aline M Rosa, et al. (2014) Simultaneous determination of gatifloxacin and prednisolone acetate in ophthalmic formulation using first-order UV derivative spectroscopy. Arab J Chem 1-6.

39. (2005) ICH harmonised tripartite guideline, validation of analytical procedures, Text and Methodology, Q2 (R1), Geneva. 